\section{Summary}

The natural history of the unshod foot was studied on the island of St. Helena, where half the islanders have gradually adopted shoe-wearing over the past few decades. Hallux valgus was found in under $2 \%$ of the unshod and in $16 \%$ of the men and $48 \%$ of the women who had worn shoes for more than 60 years.

It is a pleasure to thank Dr. C. E. Hollman, Dr. A. C. Stevenson, and Professor M. L. Rosenheim for their encouragement and advice ; Mrs. M. Parke, Miss R. A. Ash, Mr. A. Barr, and Mr. J. Scott for their statistical help; the St. Helenians for their friendly co-operation ; and Oxford University Department of Biometry for the use of their computer.

\section{REFERENCES}

Barnicot, N. A., and Hardy, R. H. (1955). 7. Anat. (Lond.), 89, 355. Brit. med. f., 1953, 2, 772 .

Camper, P."(1781). Dissertation sur la Meilleure Forme des Souliers. Amsterdam. Translation by Dowie (1861).

Dykes, R. M., Grundy, F., and Lee, H. B. (1952). Med. Offr, 87, 223.

Emslie, M. (1939). Lancet, 2, 1260.

Engle, E. T., and Morton, D. J. (1931). 7. Bone ft Surg., 13, 311.

Haines, R. W., and McDougall, A. (1954). Lancet, 2, 1308 .

James, C. S. (1939). Ibid., 2, 1390

Kalcev, B. (1963). East Africa med. 7., 40, 2, 47.

Lam Sim-Fook and Hodgson, A. R. (1958). 7. Bone 7t Surg., 40A, 1058

Wells, L. H. (1931). Amer. Э. phys. Anthrop., 15, 185.

\title{
Haemoglobin H Disease with Occlusion of Right Anterior Cerebral Artery, Xanthochromia, and Pleocytosis of C.S.F.
}

\author{
G. A. RANSOME, * F.R.C.P. ; J. L. DA COSTA,* M.R.C.P.ED., M.R.C.P.GLASG.
}

Brit. med. F., 1965, 1, 1650-1651

At present there is perhaps a tendency to minimize the clinical localization in connexion with the individual cerebral artery involved. This is largely due to the conception of remote arterial disease producing symptoms resembling thrombosis in the territories of cerebral arteries proper, and also because there is considerable overlap in the recognized syndromes. More attention is now focused on assessing the modalities involved and thereby making an anatomical diagnosis, and if it becomes necessary to recognize an individual vessel angiography will demonstrate it far more clearly than inspired guesswork.

A great deal of time and thought as well as post-mortem evidence have been spent in the past in reviewing the syndromes of the individual cerebral arterial occlusions.

The result of occlusion of the main trunk of the anterior cerebral artery depends very much on the size of the anterior communicating artery. If this is large and patent, then occlusion of the main trunk of the anterior cerebral artery will either produce no ill effects or give rise to a syndrome similar to that following thrombosis of Huebner's artery. If collateral circulation is poor the resulting syndrome is much more serious (Kiloh, 1953).

The following case is of considerable interest from the diagnostic point of view because it occurred in a patient suffering from haemoglobin $\mathrm{H}$ disease and because of the subsequent remarkable recovery.

\section{Case History}

A pale, sallow, pigmented Chinese carpenter was admitted to hospital with organic dementia and Jacksonian epilepsy. The story was that he was in his usual health until one week before admission, when he became unwell and febrile, for which he took Chinese (herbal) medicine. The following afternoon he vomited after the midday meal, and about the same time started to have recurrent Jacksonian attacks originating at the left corner of the mouth and spreading to involve the left side of the face and the left arm and hand. These attacks occurred several times a day and lasted for about a minute, but he did not lose consciousness and he continued going to work for four days. The attacks then became more frequent, so he stayed at home and at the end of the week was persuaded to come to hospital. At no stage of the illness did he have any headache or visual disturbances.
On admission he was found to have a low-grade fever and was obviously anaemic. He had a sallow, expressionless face, and melanotic pigment was noticed over the limbs, lips, and buccal mucosa. He was able to walk and talk but was extremely stupid. He was apathetic, drowsy, very slow in answering questions, and showed perseveration. From time to time Jacksonian attacks were observed; each lasted 45 seconds, and they were identical. They occurred approximately once every 15 minutes.

Neurological examination demonstrated no neck rigidity. The pupils, fundi, and visual fields were normal, although visual attention was poor. There was minimal paresis involving the left arm and face. The plantar reflexes were flexor. No sensory loss was demonstrated nor any agnosia. Double Wartenberg responses were present in both upper extremities. There was a strongly positive Rissl reflex, and grasping reflexes were present in both hands and the left foot. He had also passed urine in bed.

To sum up, the picture presented was one of organic dementia resembling advanced G.P.I. or pellagra.

At lumbar puncture on the day of admission the C.S.F. pressure was normal, but the fluid was xanthochromic and slightly turbid. The cell count was 230/c.mm., mainly lymphocytes; protein $300 \mathrm{mg} . / 100 \mathrm{ml}$, globulin was present, and the sugar $71 \mathrm{mg} . / 100$ $\mathrm{ml}$. Smear and culture were negative for organisms.

The other pathological findings are discussed below.

\section{Progress}

Within two days of admission and without specific treatment the patient began to improve rapidly. He soon became more alert and was able to answer questions quickly and rationally. No further fits occurred. Within three to four days the Rissl reflex and Wartenberg and grasp reflexes disappeared and the leftsided facial and upper-limb weakness also disappeared, and at the time of the arteriogram he was virtually well. In retrospect, he did not complain of headache and was unaware of his previous disabilities.

A second lumbar puncture three days after the first still showed faint xanthochromia, with a cell count of $70 / \mathrm{c} . \mathrm{mm}$. and a protein of $100 \mathrm{mg} . / 100 \mathrm{ml}$. It was decided to go on with the arteriogram, and this showed an occlusion of the main trunk of the right anterior cerebral artery proximal to the anterior communicating artery, with a good cross-flow from the left anterior cerebral artery through the anterior communicating artery.

\footnotetext{
* Department of Medicine, General Hospital, Singapore.
} 
His improvement seemed very rapid to all those who saw him. In retrospect it is possible that he had a superficial infarction of a portion of the brain near the motor face area. The infarction is postulated because of the xanthochromia and the considerable rise in protein. Presumably, recovery was due to a good collateral circulation and diminution of local oedema. To those who saw him initially the prognosis indeed appeared gloomy. At the end of a week it was almost unbelievable that this was indeed the same patient.

Investigations.-Red blood cell count 3,700,000/c.mm.; haemoglobin 7.8 g. $/ 100 \mathrm{ml}$; packed cell volume $30 \%$; M.C.H. $22 \mu \mu \mathrm{g}$. ; M.C.V. 82 cubic microns; total white-cell count 5,600/c.mm (normal differential count); platelet count 180,000/c.mm. Peripheral blood film showed the red blood cells to be hypochromic with moderate anisocytosis and poikilocytosis. There were a few target cells and microcytes. Haemoglobin $\mathrm{H}$ inclusion bodies were present in a brilliant-cresyl-blue preparation. Alkali-resistant haemoglobin $<1 \%$. Haemoglobin electrophoretic analysis: haemoglobin $\mathbf{A}+\mathbf{H}$. Serum iron $221 \mu \mathrm{g} . / 100 \mathrm{ml}$. Unsaturated iron-binding capacity of serum $<40 \mu \mathrm{g} . / 100 \mathrm{ml}$. Bleeding, clotting, and prothrombin times within normal limits. Blood for lupus erythematosus phenomena and latex fixation test negative. Liver-function tests normal. Blood sugar (fasting specimen) $89 \mathrm{mg} . / 100 \mathrm{ml}$. W.R. and Kahn test negative.

\section{Discussion}

There was no doubt that this man had a severe anaemia of haemoglobin $\mathrm{H}$ type. The problem was how to fit in the focal attacks with the picture of organic dementia of recent origin. The xanthochromic C.S.F. (positive Diazo reaction) showed that obviously there had been some bleeding. The excessive cells and the raised protein content suggested inflammation.

It was thought that he might have had a thrombosis of an anterior cerebral artery or that there was a more widespread thrombophlebitis, because both frontal lobes appeared to be involved. In our experience encephalitis of viral origin Japanese B does not give rise to such a high C.S.F. protein content or to xanthochromia.
The C.S.F. itself was unusual. In the many hundreds of lumbar punctures done for cerebral thrombosis the protein is occasionally raised to about $100 \mathrm{mg} . / 100 \mathrm{ml}$. and it is most unusual to find cells up to $250 / \mathrm{c} . \mathrm{mm}$. In this connexion Brain (1962) says: "The cerebrospinal fluid is usually normal except after an acute infarction, when the protein may be raised up to $100-200 \mathrm{mg} . / 100 \mathrm{ml}$. for two or three weeks, and the fluid may be xanthochromic at first. There may also be a pleocytosis, including a moderate excess of polymorphonuclear cells."

We were more inclined to take the view that there was probably superficial thrombophlebitis because of the C.S.F. changes and the involvement of both frontal lobes, although a careful search failed to reveal any phlebitis elsewhere.

Because of the xanthochromia we decided on a carotid arteriogram to exclude the possibility of a subdural haematoma. (We had one case recently in which there was no headache but only papilloedema, some drowsiness, and a xanthochromic C.S.F. with increased protein but no increase of cells.) This was to be done on the 14th day of the disease-that is, one week after admission.

\section{Summary}

A case of haemoglobin $\mathrm{H}$ disease with occlusion of the right anterior cerebral artery is described. The clinical picture was one of Jacksonian epilepsy, dementia, and paresis affecting the left arm and face. The unusual features were the xanthochromic turbid C.S.F. and the rapid recovery. A superficial cortical infarction near the motor face area is postulated. Recovery was attributed mainly to an adequate collateral circulation.

We are grateful to Dr. J. Yin for carrying out and reporting on the carotid arteriogram.

\section{REFERENCES}

Brain, W. R. (1962). Diseases of the Nervous System, 6th ed., p. 267. Oxford Univ. Press, London.

Kiloh, L. G. (1953). Postgrad. med. 7., 29, 65.

\section{Medical Memoranda}

\section{First Year's Experience in Anti-smoking Clinic}

Brit. med. F., 1965, 1, 1651-1653

Most doctors accept the importance of stopping many of their patients from smoking cigarettes. It is the single most important treatment for chronic bronchitis and it could be a farreaching measure in preventive medicine, since cigarettes cause between 40,000 and 50,000 deaths a year in Great Britain. Unfortunately, simple advice to the patients to stop smoking often proves ineffective. For this reason it was decided to see whether a group anti-smoking clinic would prove more effective.

In May 1962 a pilot clinic was started at the Central Middlesex Hospital. We now report our experience with 92 patients seen between September 1962 and June 1963, 75 of whom have been followed up for a year. Much interest has been aroused in Great Britain and abroad by this project.

\section{Patients}

The patients were referred from general practitioners, from hospital doctors, or from a chest clinic. Most of them had already failed to stop smoking on simple advice. A total of 109 patients attended. Only patients who came on three or more occasions out of a possible seven are included (mean attendance six times). Thus information on 92 patients was analysed; 62 patients were men and 30 women, aged from 16 to 68 (mean age 45). All social groups were represented. The mean cigarette consumption had been 31 daily (10 to 60) and was the same for both men and women. The reasons for attending were as follows :

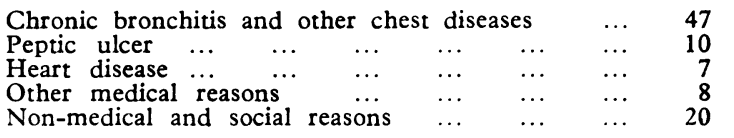

\section{The Clinic}

The clinic was run once a week in the evening for seven weeks. Fifteen to 20 patients attended each session, which lasted from one and a half hours to two hours. Apart from a radiograph of the chest, patients were not physically examined, but each filled in a questionary on his smoking habits.

Experience has shown that three essentials are required for an effective clinic: an enthusiastic doctor, and preferably one who 